\title{
Penerapan Metode SAW dan Fuzzy Dalam Sistem Pendukung Keputusan Penerimaan Beasiswa
}

\author{
Application of SAW and Fuzzy Method \\ in Decision Support System Scholarship \\ Risa Helilintar*1, Wing Wahyu Winarno ${ }^{2}$, Hanif Al Fatta ${ }^{3}$ \\ ${ }_{1,2.3}$ Magister Teknik Informatika STMIK AMIKOM Yogyakarta \\ E-mail: *11 risa.helilintar@gmail.com, ${ }^{2}$ wing@amikom.ac.id, ${ }^{3}$ hanif.a@ amikom.ac.id
}

\begin{abstract}
Abstrak
Database Model Fuzzy Tahani dan SAW merupakan saatu metode yang dapat digunakan pada proses pengambilan keputusan. Sesuai dengan peraturan pihak Intansi yang memberikan beasiswa unuk memperoleh beasiswa, maka diperlukan kriteria-kriteria untuk menentukan siapa yang akan terpilih untuk menerima beasiswa. Pembagian beasiswa dilakukan untuk membantu penentuan dalam merekomendasikan seseorang yang layak menerima beasiswa maka dibutuhkan sistem pendukung keputusan.

Penelitian ini membahas tentang seleksi penerimaan beasiswa dengan metode Fuzzy Database Tahani dan SAW. Penelitian ini dapat membantu KaProdi Teknik Informatika maupun Prodi-Prodi lain di UNP kediri untuk menentukkan penerima beasiswa. Penelitian ini bertujuan untuk memadukan metode Fuzzy dan SAW dengan ketentuan dan kriteria yang sudah ditentukan oleh pihak Universitas. Sistem yang akan dibuat harus mampu menentukan perangkingan untuk rekomendasi penerima beasiswa. Penelitian menggunakan metode fuzzy yaitu untuk menentukan nilai input ke SAW sebagai dasar nilai input. Hasil yang didapat pada penelitian ini yaitu berupa rangking dan selanjutnya akan dibuat rekomendasi untuk penerima beasiswa.
\end{abstract}

Kata Kunci-Beasiswa, SPK, Fuzzy, SAW.

Database fuzzy Tahani and SAW is the other, a method that can be used in the decision making process. In accordance with the regulation which provides scholarships instance transform and obtaining scholarships, the necessary criteria to determine who will be selected to receive a scholarship. The scholarship division. To assist in the determination of a person recommend the eligible then takes a decision support system.

This study discusses the selection of scholarship acceptance by Fuzzy Database Tahani and SAW. This research can help leadership courses Informatics and other study program-UNP Kediri to determine recipients. This research aims to integrate Fuzzy and SAW with the rules and criteria set by the university. The system being designed to be able to determine rankings to recommendation recipients. Research using fuzzy method is to determine the value of the input to the $S A W$ as the basis of input values. The results obtained in this study in the form of ranking and then make a recommendation to the receiving scholarships.

Keywords - Schoolarship, Decision Support Systems, Fuzzy, Saw. 


\section{PENDAHULUAN}

\subsection{Latar Belakang}

Menyadari bahwa pendidikan sangat penting, negara sangat mendukung setiap warga negaranya untuk meraih pendidikan setinggi-tingginya. Melakukan program pendidikan gratis dan program beasiswa. Beasiswa dapat dikatakan pembiayaan yang tidak bersumber dari pendanaan sendiri atau orang tua, akan tetapi diberikan oleh pemerintah, perusahaan swasta, kedutaan, Universitas, serta lembaga pendidik. Biaya tersebut diberikan kepada yang berhak menerima sesuai dengan kriteria yang ditentukan.

Pada kondisi saat ini yaitu Proses Penyeleksian yang dilakukan masih secara manual sementara persyaratan yang akan menjadi penilaian cukup banyak mulai dari transkrip nilai, slip gaji, surat keterangan tidak mampu bagi yang mengajukan BBM, jumlah tanggungan orang tua, sedangkan waktu yang diberikan pihak Universitas Nusantara PGRI Kediri untuk melakukan pendaftaran mahasiswa satu minggu setelah surat edaran pengumuman beasiswa keluar dan biasanya edaran keluar setiap liburan semester jadi mahasiswa banyak yang tidak mengetahui. Dan pihak penyeleksi hanya diberi waktu dua hari untuk memutuskan siapa yang berhak menerima beasiswa yang diusulkan, sehingga proses penyeleksian tidak dapat dilakukan secara baik dan benar karena waktu yang diberikan tidak efisien dengan penyeleksian yang dilakukan secara manual, jika dilakukan secara baik dan benar maka butuh ketelitian dan waktu yang cukup lama untuk melakukan proses penyeleksian.

Beberapa metode pernah diusulkan oleh para peneliti sebelumnya: untuk proses pemilihan program studi dengan menggunakan Logika fuzzy Metode Fuzzy Multi-Attribute Decision Making (FMADM) dan menggunakan metode ini dapat memberikan alternatif terbaik dalam memilih program studi (Rohayani, 2013)[5]. Untuk mengatasi kriteria pemilihan calon penerima beasiswa yang maka digunakan logika Fuzzy Multiple Attribute Decision Making (Fuzzy MADM). Metode SAW adalah metode yang digunakan untuk mencari alternatif optimal dari sejumlah alternatif dengan kriteria tertentu. Metode SAW dipilih karena untuk menentukan nilai bobot untuk setiap atribut, kemudian dilanjutkan dengan perangkingan yang akan menyeleksi penerima beasiswa (Putra, 2011)[4].

Pada penelitian yang dilakukan oleh (Nasution, 2014) dengan judul Sistem Pendukung Keputusan Penentuan Pemilihan Laptop Dengan Menerapkan Fuzzy Tahani, pada penelitian ini mengimplementasikan pendekatan logika fuzzy pada penentuan spesifikasi komputer untuk suatu paket komputer lengkap, sesuai dengan kebutuhan masing-masing pembeli, baik dari segi merek maupun logika fuzzy seperti kecepatan prosesor, kapasitas harddisk, kapasitas memory, ukuran monitor, ukuran power supply, serta ukuran VGA. Hasil dari pengujian terhadap sistem, dengan 10 orang sampel pengguna, didapatkan tingkat akurasi sebesar $68 \%$.[3]

Penelitian (Efendi, 2014)[6] yang berjudul Aplikasi Fuzzy Database Model Tahani Dalam Memberikan Rekomendasi Pembelian Rumah Berbasis Web Fuzzy Dalam penelitian ini, aplikasi fuzzy database model Tahani dibangun untuk membantu pihak developer perumahan dalam memberikan rekomendasi rumah kepada konsumen, sehingga konsumen dapat memilih rumah sesuai dengan kriteria yang dipilihnya dengan lebih cepat dan mudah. Pada aplikasi yang telah dibangun, hasil rekomendasi rumah didasarkan pada nilai derajat keanggotaan dan fire strength (nilai kebenaran) dari proses perhitungan di dalam aplikasi tersebut. Hasil dari aplikasi ini yaitu berupa lima nilai terbaik hasil rekomendasi rumah dan diurutkan berdasarkan nilai tertinggi sampai dengan terendah. 
Citec Journal, Vol. 3, No. 2, Februari 2016 - April 2016

ISSN: 2354-5771

\subsection{Rumusan Masalah}

Berdasarkan latar belakang yang telah diuraikan diatas, maka dapat dirumuskan beberapa masalah sebagai berikut:

a. Bagaimana merancang sebuah sistem pendukung keputusan untuk menentukan Mahasiswa penerima Beasiswa.

b. Bagaimana Metode Fuzzy dan dan SAW dapat memberikan solusi dalam permasalahan penerima Beasiswa?

\subsection{Batasan Variabel Penelitian}

Pada dasarnya permasalahan dalam beasiswa ini cukup luas, tetapi agar sesuai yang telah direncanakan sebelumnya diperlukan batasan-batasan agar tujuan penelitian dapat tercapai. Adapun batasan-batasan dalam penelitian ini sebagai berikut:

a. Metode yang digunakan yaitu Fuzzy dan SAW.

b. Bagaiman metode SAW dan Fuzzy dapat memberikan solusi dalam permasalahan penerima beasiswa.

c. Sistem ini dibuat hanya pada kasus Penerimaan Beasiswa.

\subsection{Tujuan Penelitian}

Berdasarkan permasalahan yang diteliti, maka tujuan yang ingin di capai dari pembangunan aplikasi penerapan metode saw dan fuzzy dalam sistem pendukung keputusan peneriman beasiswa ini adalah:

a. Membangun Aplikasi menggunakan metode Fuzzy dan SAW yang transparan dalam pemilihannya.

b. Membangun Aplikasi sistem pendukung keputusan untuk membantu dalam menentukan siapa saja yang layak mendapatkan beasiswa berdasarkan kriteria yang sudah ditentukan oleh Universitas Nusantara PGRI Kediri.

c. Untuk membatu memberikan alternatif keputusan dalam penentuan penerina Beasiswa.

\subsection{Manfaat Penelitian}

Berdasarkan analisis permasalahan yang telah diteliti, adapun manfaat penelitian ini adalah ssebagai berikut

a. Dapat membantu memudahkan kerja tim penyeleksi beasiswa dalam menentukancalon penerima beasiswa.

b. Dapat mengurangi kesalahan dalam menentukan penerima beasiswa.

c. Dapat mempercepat proses peyeleksian beasiswa.

\section{METODE PENELITIAN}

\subsection{Metode Penelitian}

Dalam penelitian ini menggunakan metode penelitian Action Research adalah penelitian baik kualitatif maupun kuantitatif. Penelitian tindakan adalah cara melakukan masalah pada saat yang bersamaan. Penelitian tindakan ini merupakan metode yang didasarkan pada tindakan masyarakat yang seringkali diselenggarakan pada suatu latar yang luas, seperti di rumah sakit, pabrik, sekolah, dan lain sebagainya (Hasibuan, 2007). 


\subsection{Alur Penelitian}

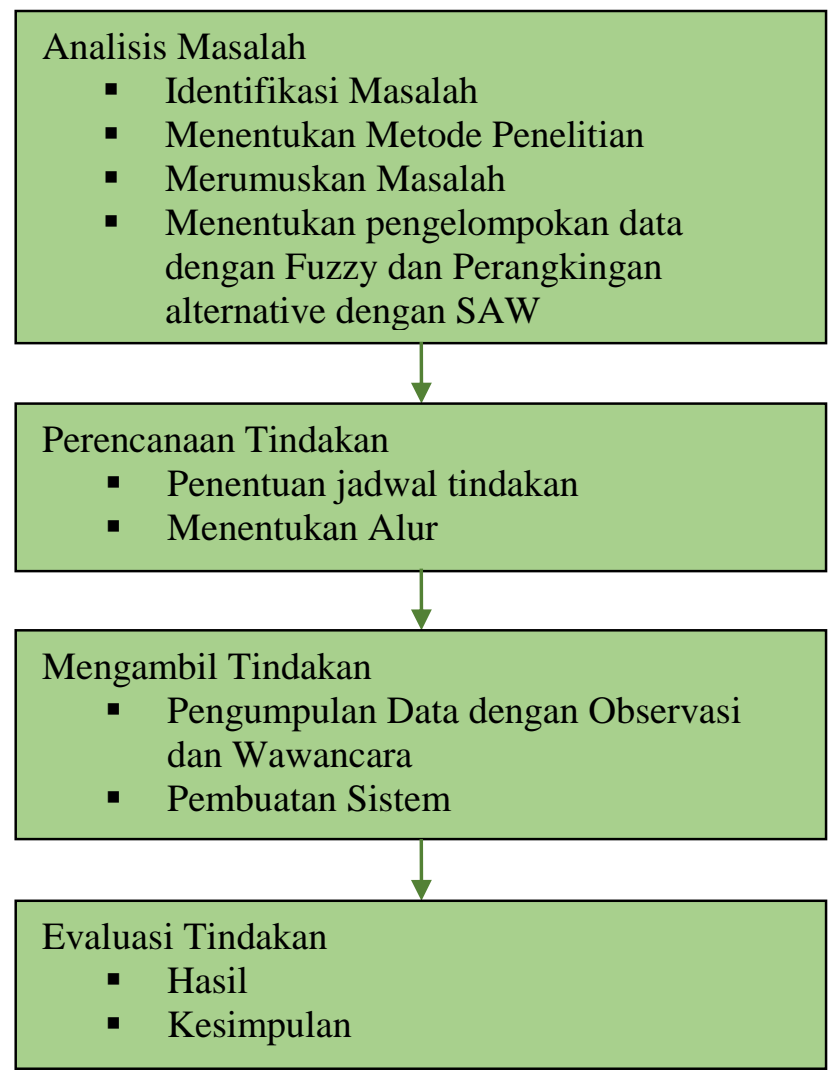

Gambar 1. Alur Penelitian

\subsection{Landasan Teori}

\subsubsection{Beasiswa}

Beasiswa adalah pemberian berupa bantuan keuangan yang diberikan kepada perorangan yang bertujuan untuk digunakan demi keberlangsungan pendidikan yang ditempuh. Beasiswa dapat diberikan oleh lembaga pemerintah, perusahaan ataupun yayasan. Pemberian beasiswa dapat dikategorikan pada pemberian Cuma-Cuma ataupun pemberian dengan ikatan kerja (bisa disebut ikatan dinas) setelah selesainya pendidikan.

\subsubsection{Pengertian $S P K$}

Turban, Rainer, Potter (20015: 321) bukunya yang berjudul Introduction to Information technology, menyebutkan bahwa Sistem Pendukung Keputusan adalah suatu sistem informasi berbasis computer mengkombinasikan model dan data untuk menyediakan dukungan kepada pengambil keputusan dalam memecahkan masalah semiterstruktur atau masalah ketergantungan yang melibatkan user secara mendalam [2].

\subsubsection{Fuzzy Database Tahani}

Fuzzy database model Tahani ini masih tetap menggunakan relasi standar, hanya saja model ini menggunakan teori himpunan fuzzy untuk mendapatkan informasi pada query-nya (Hari dan Kusumadewi, 2004). Tahani mendeskripsikan suatu metode pemrosesan query fuzzy dengan didasarkan atas manipulasi bahasa yang dikenal dengan nama SQL. Dengan menggunakan basis data standar, dapat dicari data karyawan dengan spesifikasi tertentu dengan 
menggunakan query. Misalnya diinginkan informasi tentang nama-nama karyawan yang usianya kurang dari 35 tahun, maka bisa diciptakan suatu query berikut: SELECT NAMA FROM KARYAWAN WHERE (umur < 35) Sehingga muncul nama-nama Lia, Kiki, dan Yoga. Apabila diinginkan informasi tentang nama-nama karyawan yang gajinya lebih dari 1 juta rupiah, maka bisa diciptakan query berikut: SELECT 26 NAMA FROM KARYAWAN WHERE (gaji > 1000000) Sehingga muncul nama- nama iwan, Sari, Andi, Amir, dan Rian. Apabila diinginkan informasi tentang nama-nama karyawan yang masa kerjanya kurang dari atau sama dengan 5 tahun tetapi gajinya sudah lebih dari 1 juta rupiah, maka bisa dic iptakan suatu query: SELECT NAMA FROM KARYAWAN WHERE MasaKerja<=5) and (Gaji > 1000000). Sehingga muncul nama-nama Andi dan Rian. Metode fuzzy database model Tahani tersusun atas tahapan, yaitu:

1. Representasi linier, Representasi Kurva Segitiga, Representasi Kurva Trapesium Masingmasing fungsi tersebut, akan menghasilkan nilai antara " 0 " dan " 1 " dengan cara yang berbeda, sesuai dengan jenis representasi yang digunakan. Apabila $\mu \mathrm{S}$ adalah fungsi keanggotaan suatu elemen pada himpunan $\mathrm{S}$ maka untuk suatu elemen X dapat dinyatakan $\mu \mathrm{S}(\mathrm{X})$ yang bernilai antara "0" dan 27 "1" sehingga ada tiga kemungkinan [7]: $\mu \mathrm{S}(\mathrm{X})=1 \rightarrow$ $\mathrm{X}$ mutlak anggota $\mathrm{S} . \mu \mathrm{S}(\mathrm{X})=0 \rightarrow \mathrm{X}$ mutlak bukan anggota $\mathrm{S} . \mu \mathrm{S}(\mathrm{X})<1 \rightarrow \mathrm{X}$ anggota $\mathrm{S}$ dengan derajat keanggotaan antara 0 dan 1.

2. Fuzzyfikasi adalah fase pertama dari perhitungan fuzzy yaitu pengubahan nilai tegas ke nilai fuzzy. Prosesnya adalah sebagai berikut: suatu besaran analog dimasukkan sebagai input (crisp input), lalu input tersebut dimasukkan pada batas scope/dominan dari membership function. Membership function ini biasanya dinamakan membership function input. Output dari proses fuzzifikasi ini adalah sebuah nilai input fuzzy atau yang biasanya dinamakan fuzzy input.

3. Fuzzyfikasi Query diasumsikan sebuah query konvensional (nonfuzzy) DBMS yang akan mencoba membuat dan menerapkan sebuah system dasar logika fuzzy query (fuzzy logic based querting system). Konsep dari sebuah relasi fuzzy dalam sebuah DBMS menggunakan derajat keanggotaan $\mu$ yang didefinisikan pada kumpulan domain $\mathrm{X}=(\mathrm{X} 1, \ldots, \mathrm{Xn})$, dan telah di-generate pada relasi luar oleh nilai tengah fuzzy. Sintaks query yang digunakan adalah sebagai berikut: "select from where".

4. Operator Dasar Zadeh untuk Operasi himpunan fuzzy pada seperti himpunan konvensional, ada beberapa operasi yang diidentifikasikan secara khusus untuk mengombinasikan dan memodifikasi himpunan fuzzy. Nilai keanggotaan sebagai dari 2 himpunan fuzzy dikenal dengan nama Fire Strength atau $\alpha$-predikat. Sangat mungkin digunakan operator dasar dalam proses query berupa operator AND dan OR [7]. $\alpha$ - predikat sebagai hasil operasi dengan operator AND diperoleh dengan mengambil nilai keanggotaan terkecil antar elemen pada himpunan-himpunan yang bersangkutan, dinotasikan : $\mu \mathrm{A} \cap \mathrm{B}=\min (\mu \mathrm{A}[\mathrm{x}], \mu \mathrm{B}[\mathrm{x}])$. Sedangkan untuk hasil operasi dengan operator OR diperoleh dengan mengambil nilai keanggotaan terbesar antar elemen pada himpunan-himpunan yang bersangkutan, dinotasikan: $\mu \mathrm{AUB}=\max (\mu \mathrm{A}[\mathrm{x}], \mu \mathrm{B}[\mathrm{x}])$. Alternatif yang direkomendasikan adalah alternatif yang memiliki nilai Fire Strength atau tingkat kesesuaian dengan kriteria pilihan di atas angka 0 (nol) sampai dengan angka 1 (satu).[1]

\subsection{4. $S A W$}

Menurut Fishburn (2006 : 74), dalam membangun DSS ini akan diterapkan metode SAW (Simple Additive Weighting) dalam menyelesaikan masalah Multi Attribute Decision Making yang dihadapi. Metode SAW sering juga dikenal istilah metode penjumlahan terbobot. Konsep dasar metode SAW adalah mencari penjumlahan terbobot dari rating kinerja pada setiap alternatif pada semua atribut. Metode SAW membutuhkan proses normalisasi matriks keputusan (X) ke suatu skala yang dapat diperbandingkan dengan semua rating alternatif yang ada. 
Berikut adalah persamaan yang ada dalam metode SAW (Kusumadewi, 2006) : [1]

$$
r_{i j}=\left\{\begin{array}{lc}
\frac{x_{i j}}{\operatorname{Max}_{i} x_{i j}} & \text { Jika j adalah atribut keuntungan (benefit) } \\
\frac{\operatorname{Min}_{i}}{x_{i j}} & \text { Jika j adalah atribut biaya (cost) }
\end{array}\right.
$$

Keterangan :

$\mathrm{R}_{\mathrm{ij}} \quad=$ nilai rating kinerja normalisasi

$\mathrm{X}_{\mathrm{ij}} \quad=$ nilai atribut yang dimiliki dariu setiap kriteria

$\operatorname{Max} x_{i j} \quad=$ nilai terkecil dari setiap kriteria

Benefit = nilai terbesar adalah terbaik

Cost $\quad=$ nilai terkecil adalah terbaik

Dimana $r_{i j}$ adalah rating kinerja ternormalisasi dari alternative Ai pada atribut $\mathrm{Cj} ; \mathrm{i}=1,2, \ldots, \mathrm{m}$ dan $\mathrm{j}=1,2, \ldots, \mathrm{n}$

$$
V_{i}=\sum_{j=1}^{n} w_{j} r_{i j}
$$

Keterangan :

$\mathrm{V}_{\mathrm{i}} \quad=$ nilai Akhir Alternatif

$\mathrm{W}_{\mathrm{i}} \quad=$ Bobot yang telah ditentukan

$\mathrm{R}_{\mathrm{ij}} \quad=$ Normalisasi matriks

Nilai $V_{i}$ yang lebih besar mengindikasikan bahwa alternative ai lebih terpilih.

\subsection{Analisis dan Perancangan Sistem}

\subsubsection{Analisis Metode Fuzzy}

Berikut adalah langkah-langkah penyelesaian untuk menentukan nilai input dengan menggunakan metode fuzzy.

1. Menentukan kriteria yang akan dijadikan acuan pengambilan kepuusan.

Tabel 1. Tabel Kriteria

\begin{tabular}{|l|l|}
\hline \multicolumn{1}{|c|}{ Kriteria } & \multicolumn{1}{c|}{ Keterangan } \\
\hline C1 & IPK \\
\hline C2 & Penghasilan Orang Tua \\
\hline C3 & Sertifikat UKM \\
\hline C4 & Jml Tanggungan Orang Tua \\
\hline C5 & Semester \\
\hline
\end{tabular}

Kriteria dibagi menjadi dua kategori yaitu benefit (keuntungan) dan cost (biaya). Kriteria dikatakan benefit jika kriteria tersebut nilainya akan maksimumkan sedangkan kriteria dikatgorikan benefit jika kriteria tersebut nilainya akan minimumkan. Kriteria yang dikategorikan benefit yaitu IPK, Semester dan jumlah tanggungan orang tua. Sedangkan yang diktegorikan kriteria cost yaitu Penghasilan Orang Tua. 
Citec Journal, Vol. 3, No. 2, Februari 2016 - April 2016

ISSN: 2354-5771

2. Menggambarkan Fungsi Keanggotaan

Fungsi Keanggotaan (membership function) adalah satu kurva yang menunjukkan pemetaan titik-titik input data ke dalam nilai anggotanya.

3. Fuzzyfikasi

Perhitungan Fuzzy yaitu pengubahan nilai tegas ke nilai fuzzy. Variabel bobot Ipk dikonversikan dengan bilangan fuzzy di bawah ini:

Tabel 2. Kriteria Bobot IPK

\begin{tabular}{|l|l|l|}
\hline \multicolumn{1}{|c|}{ IPK } & \multicolumn{1}{c|}{ Bilangan Fuzzy } & \multicolumn{1}{c|}{ Nilai } \\
\hline $\mathrm{X} \leq=2,75$ & Sangat Rendah & 0 \\
\hline $2,75<\mathrm{X} \leq=3,00$ & Rendah & 0,25 \\
\hline $3,00<\mathrm{X} \leq=3,25$ & Cukup & 0,5 \\
\hline $3,25<\mathrm{X} \leq=3,50$ & Tinggi & 0,75 \\
\hline $\mathrm{X}>3,50$ & Sangat Tinggi & 1 \\
\hline
\end{tabular}

Variabel bobot penghasilan orang tua dikonversikan dengan bilangan fuzzy di bawah ini.

Tabel 3. Kriteria Penghasilan Orang Tua

\begin{tabular}{|l|l|l|}
\hline \multicolumn{1}{|c|}{ Penghasilan } & \multicolumn{1}{|c|}{ Bilangan Fuzzy } & \multicolumn{1}{c|}{ Nilai } \\
\hline $\mathrm{X} \leq=1.000 .000$ & Rendah & 0,25 \\
\hline $1.000 .000<\mathrm{X} \leq=2.000 .000$ & Cukup & 0,5 \\
\hline $2.000 .000<\mathrm{X} \leq=4.000 .000$ & Tinggi & 0,75 \\
\hline $\mathrm{X}>4.000 .000$ & Sangat Tinggi & 1 \\
\hline
\end{tabular}

Variabel bobot Prestasi Akademik dikonversikan dengan bilangan fuzzy di bawah ini.

Tabel 4. Kriteria Prestasi Akademik

\begin{tabular}{|l|l|l|}
\hline \multicolumn{1}{|c|}{ JML Sertifikat } & \multicolumn{1}{c|}{ Bilangan Fuzzy } & \multicolumn{1}{c|}{ Nilai } \\
\hline 1 Sertifikat & Sangat Sedikit & 0 \\
\hline 2 Sertifikat & Sedikit & 0,25 \\
\hline 3 Sertifikat & Sedang & 0,5 \\
\hline 4 Sertifikat & Banyak & 0,75 \\
\hline$>$ S Sertifikat & Sangat Banyak & 1 \\
\hline
\end{tabular}

Variabel bobot Jumlah Tanggungan Orang Tua dikonversikan dengan bilangan fuzzy di bawah ini.

Tabel 5. Kriteria Penghasilan Orang Tua

\begin{tabular}{|l|l|l|}
\hline \multicolumn{1}{|c|}{$\begin{array}{c}\text { Jml Tanggungan } \\
\text { Orang Tua }\end{array}$} & \multicolumn{1}{|c|}{ Bilangan Fuzzy } & Nilai \\
\hline 1 Anak & Sangat Sedikit & 0 \\
\hline 2 Anak & Sedikit & 0,25 \\
\hline 3 Anak & Sedang & 0,5 \\
\hline 4 Anak & Banyak & 0,75 \\
\hline$>5$ Anak & Sangat Banyak & 1 \\
\hline
\end{tabular}


Variabel bobot Semester dikonversikan dengan bilangan fuzzy di bawah ini.

Tabel 6. Kriteria Semester

\begin{tabular}{|l|l|c|}
\hline \multicolumn{1}{|c|}{ Semester } & \multicolumn{1}{|c|}{ Bilangan Fuzzy } & Nilai \\
\hline $\mathrm{X} \leq=2$ & Sangat Rendah & 0 \\
\hline $2<\mathrm{X} \leq=3$ & Rendah & 0,25 \\
\hline $3<\mathrm{X} \leq=4$ & Tengah & 0,5 \\
\hline $5<\mathrm{X} \leq=7$ & Tinggi & 0,75 \\
\hline 7 & Sangat Tinggi & 1 \\
\hline
\end{tabular}

4. Fuzzyfikasi Query

Fuzzyfikasi Query diasumsikan sebuah query konvensional (nonfuzzy) DBMS yang akan mencoba membuat dan menerapkan sebuah sistem dasar logika query.

Tabel 7. Tabel Hasil Fuzzy Query

\begin{tabular}{|c|l|l|l|l|l|l|l|}
\hline NO & \multicolumn{1}{|c|}{ NPM } & \multicolumn{1}{|c|}{ Nama } & $\begin{array}{c}\text { IPK } \\
\text { Tinggi }\end{array}$ & $\begin{array}{c}\text { Penghasil } \\
\text { an Ortu } \\
\text { Rendah }\end{array}$ & $\begin{array}{c}\text { Prestasi } \\
\text { Akademik } \\
\text { Tinggi }\end{array}$ & $\begin{array}{c}\text { Jml } \\
\text { Tanggungan } \\
\text { Ortu Sangat } \\
\text { Banyak }\end{array}$ & $\begin{array}{l}\text { Semester } \\
\text { Sangat } \\
\text { Tinggi }\end{array}$ \\
\hline 1 & 14.1 .03 .02 .0038 & Achmaddani Setyo N & 0,25 & 0,75 & 0,5 & 0,75 & 0 \\
\hline 2 & 13.1 .03 .02 .0037 & Adam Amirudin & 0,75 & 0 & 0,75 & 0 & 0,5 \\
\hline 3 & 12.1 .03 .02 .0111 & $\begin{array}{l}\text { Ahmad Saeful } \\
\text { Anwar }\end{array}$ & 0,5 & 0 & 0 & 0 & 0,75 \\
\hline 4 & 12.1 .03 .02 .0241 & $\begin{array}{l}\text { Alahudin } \\
\text { Abdurahman A. }\end{array}$ & 0,75 & 0,5 & 0,25 & 0,5 & 0,75 \\
\hline 5 & 14.1 .03 .02 .0036 & Aliffando Pratama P & 1 & 0,25 & 1 & 0,25 & 1 \\
\hline
\end{tabular}

\subsubsection{Analisis Metode SAW}

Tahap-tahap yang dilakukan pada metode SAW yaitu:

1. Menentukan kriteria-kriteria yang akan dijadikan acuan dalam pengambilan keputusan, yaitu $\mathrm{Ci}$

Tabel 8. Tabel Kriteria

\begin{tabular}{|l|l|}
\hline \multicolumn{1}{|c|}{ Kriteria } & \multicolumn{1}{c|}{ Keterangan } \\
\hline C1 & IPK \\
\hline C2 & Penghasilan Orang Tua \\
\hline C3 & Sertifikat UKM \\
\hline C4 & Jml Tanggungan Orang Tua \\
\hline C5 & Semester \\
\hline
\end{tabular}


Citec Journal, Vol. 3, No. 2, Februari 2016 - April 2016

ISSN: 2354-5771

2. Menentukan rating kecocokan setiap alternative pada setiap kriteria

Berdasarkan data pemohon di atas dapat dibentuk matriks keputusan $\mathrm{X}$ yang telah dikonversikan dengan bilangan fuzzy sebagai berikut:

Tabel 9. Rating Kecocokan Setiap Alternatif Pada Setiap Kriteria

\begin{tabular}{|l|l|l|l|l|l|}
\hline \multirow{2}{*}{ Alternatif } & \multicolumn{5}{|c|}{ Kriteria } \\
\cline { 2 - 6 } & \multicolumn{1}{|c|}{ C1 } & \multicolumn{1}{c|}{ C2 } & \multicolumn{1}{c|}{ C3 } & \multicolumn{1}{c|}{ C4 } & \multicolumn{1}{c|}{ C5 } \\
\hline A1 & 0,25 & 0,75 & 0,5 & 0,75 & 0 \\
\hline A2 & 0,75 & 0 & 0,75 & 0 & 0,5 \\
\hline A3 & 0,5 & 0 & 0 & 0 & 0,75 \\
\hline A4 & 0,75 & 0,5 & 0,25 & 0,5 & 0,75 \\
\hline A5 & 1 & 0,25 & 1 & 0,25 & 1 \\
\hline
\end{tabular}

Penentuan nilai vector bobot berdasarkan tingkat kepentingan masing-masing kriteria pada beasiswa. Kriteria yang paling diutamakan adalah IPK, Prestasi non akademik, Jumlah tanggungan orang tua, semester. Maka nilai bobot vektor $\mathrm{W}$ adalah sebagai berikut :

\section{Vektor Bobot : $W=[1,0,25,1,1,1]$}

3. Membuat matriks keputusan berdasarkan criteria (Ci)

Kemudian melakukan normalisasi matriks berdasarkan persamaan yang disesuaikan dengan jenis atribut (atribut keuntungan ataupun atribut biaya) sehingga diperoleh matriks ternormalisasi R. Membuat matriks keputusan X, dibuat dari table kecocokan sebagai berikut:

$$
X=\left\{\begin{array}{lllll}
0,25 & 0,75 & 0,5 & 0,75 & 0 \\
0,75 & 0 & 0,75 & 0 & 0,5 \\
0,5 & 0 & 0 & 0 & 0,75 \\
0,75 & 0,5 & 0,25 & 0,5 & 0,75 \\
1 & 0,25 & 1 & 0,25 & 1
\end{array}\right.
$$

Pertama, dilakukan normaslisasi matrik X untuk menghitung nilai masing-masing kriteria berdasarkan kriteria diasumsikan, sebagai kriteria keuntungan atau biaya sebagai berikut:

$$
\mathrm{R}=\left\{\begin{array}{llcll}
1 & 2 & 1 & 0,25 & 1 \\
0,75 & 1 & 0,75 & 0,25 & 0,5 \\
0,75 & 1 & 0,25 & 0,5 & 0,75 \\
0,25 & 0,5 & 0,5 & 0,75 & 0,25 \\
0,5 & 1 & 0,5 & 0,25 & 0,75
\end{array}\right.
$$

4. Hasil akhir diperoleh dari proses perankingan yaitu penjumlahan dari perkalian matriks ternormalisasi $\mathrm{R}$ dengan vektor bobot sehingga diperoleh nilai terbesar yang dipilih sebagai alternatif terbaik (Ai) sebagai solusi.

Selanjutnya akan dibuat perkalian matriks $\mathrm{W}^{*} \mathrm{R}$ dan penjumlahan hasil perkalian untuk memperoleh alternatif terbaik dengan melakukan perangkingan nilai terbesar sebagai berikut:

$$
\begin{aligned}
& \mathrm{V} 1=(1)(0,25)+(2)(0,10)+(1)(0,25)+(0,25)(0,20)+(1)(0,20)=1,25 \\
& \text { V2 }=(0,75)(0,25)+(1)(0,10)+(0,75)(0,25)+(0,25)(0,20)+(0,5)(0,20)=0,625 \\
& \text { V3 }=(0,75)(0,25)+(1)(0,10)+(0,25)(0,25)+(0,5)(0,20)+(0,75)(0,20)=0,6 \\
& \text { V4 }=(0,25)(0,25)+(0,5)(0,10)+(0,5)(0,25)+(0,75)(0,20)+(0,25)(0,20)=0,4375 \\
& \text { V5 }=(0,5)(0,25)+(1)(0,10)+(0,5)(0,25)+(0,25)(0,20)+(0,75)(0,20)=0,9
\end{aligned}
$$


Hasil Perangkingan diperoleh: V1 $=1,25, \mathrm{~V} 2=0,625, \mathrm{~V} 3=0,6, \mathrm{~V} 4=0,4375, \mathrm{~V} 5=0,9$. Nilai terbesar ada pada V1 dan V2 dengan demikian alternative A1 dan A2 adalah Alternatif yang terpilih sebagai Alternatif terbaik.

\section{HASIL DAN PEMBAHASAN}

\subsection{Hasil}

Tampilan Menu utama Sistem Pendukung Keputusan dengan Logika Fuzzy dan SAW.

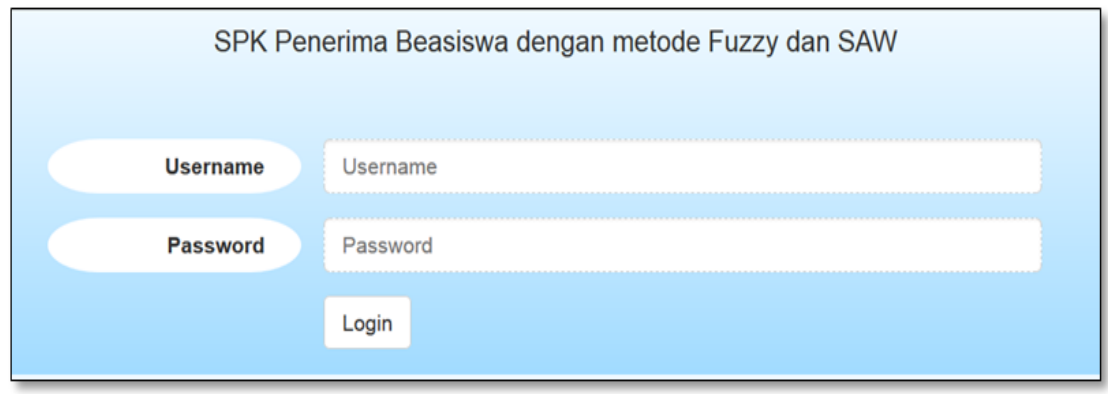

Gambar 2. Tampilan Utama Sistem

Pada menu input data Mahasiswa ada beberapa menu kriteria yang harus di isi diantaranya, Nama, Prestasi Akademik, Semester, NIM, Penghasilan Ortu, Jumlah tanggungan Orangtua.

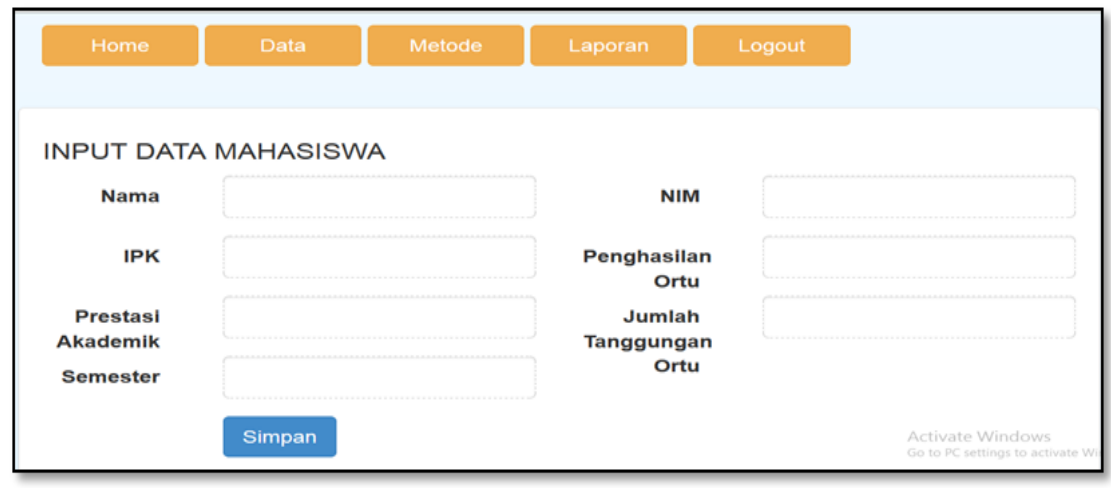

Gambar 3. Input Data Mahasiswa 
Citec Journal, Vol. 3, No. 2, Februari 2016 - April 2016

ISSN: 2354-5771

Setelah semua data Mahasiswa beserta kriteria di input berikut tampilan daftar data Mahasiswa beserta kriterianya.

\begin{tabular}{|c|c|c|c|c|c|c|c|c|}
\hline \multicolumn{9}{|c|}{ DAFTAR DATA MAHASISWA } \\
\hline No & Nama & NIM & IPK & $\begin{array}{l}\text { Penghasilan } \\
\text { Ortu }\end{array}$ & $\begin{array}{l}\text { Prestasi } \\
\text { Akademik }\end{array}$ & $\begin{array}{l}\text { Jumlah } \\
\text { Tanggungan Ortu }\end{array}$ & Semester & Aksi \\
\hline 1 & $\begin{array}{l}\text { Amirudin } \\
\text { Sukma } \\
\text { Hanggara }\end{array}$ & 10.1 .03 .02 .0051 & 3.17 & 3000000 & 2 & 1 & 5 & \begin{tabular}{|l} 
Hapus \\
EDIT \\
\end{tabular} \\
\hline 2 & $\begin{array}{l}\text { Arik Dwi } \\
\text { malinda }\end{array}$ & 10.1 .03 .02 .0094 & 3.20 & 2500000 & 3 & 1 & 5 & $\begin{array}{l}\text { Hapus } \\
\text { EDIT }\end{array}$ \\
\hline 3 & Astutik & 10.1 .03 .02 .0103 & 3.61 & 2000000 & 3 & 2 & 5 & $\begin{array}{l}\text { Hapus } \\
\text { EDIT }\end{array}$ \\
\hline 4 & Arga Adinata & 10.1 .03 .02 .0088 & 3.20 & 2700000 & 2 & 1 & 5 & $\begin{array}{l}\text { Hapus } \\
\text { EDIT } \\
\end{array}$ \\
\hline 5 & Donny Hidayat & 09.1 .03 .02 .0181 & 3.59 & 2000000 & 2 & 2 & 7 & $\begin{array}{l}\text { Hapus } \\
\text { EDIT }\end{array}$ \\
\hline 6 & $\begin{array}{l}\text { Endang Restu } \\
\text { Patmawati }\end{array}$ & 09.1 .03 .02 .0200 & 3.16 & 3240000 & 3 & 1 & $\begin{array}{l}7 \text { Activate } \\
\text { Go to PC se }\end{array}$ & $\begin{array}{l}\text { Hapus } \\
\text { EDIT }\end{array}$ \\
\hline
\end{tabular}

Gambar 4. Tampilan Data Mahasiswa

Setelah semua data selesai diinput maka akan dilakukan Perhitungan Fuzzy yaitu pengubahan nilai tegas ke nilai fuzzy dan selanjutnya akan dijadikan nilai input ke SAW.

\begin{tabular}{|c|c|c|c|c|c|c|c|}
\hline \multicolumn{8}{|c|}{ Fuzzyfikasi } \\
\hline No & Nama & NIM & IPK & $\begin{array}{l}\text { Penghasilan } \\
\text { Ortu }\end{array}$ & $\begin{array}{l}\text { Prestasi } \\
\text { Akademik }\end{array}$ & $\begin{array}{l}\text { Jumlah } \\
\text { Tanggungan Ortu }\end{array}$ & Semester \\
\hline 1 & $\begin{array}{l}\text { Amirudin Sukma } \\
\text { Hanggara }\end{array}$ & 10.1 .03 .02 .0051 & 0.5 & 0.75 & 0.25 & 0 & 0.75 \\
\hline 2 & Arik Dwi malinda & 10.1 .03 .02 .0094 & 0.5 & 0.75 & 0.5 & 0 & 0.75 \\
\hline 3 & Astutik & 10.1 .03 .02 .0103 & 1 & 0.5 & 0.5 & 0.25 & 0.75 \\
\hline 4 & Arga Adinata & 10.1 .03 .02 .0088 & 0.5 & 0.75 & 0.25 & 0 & 0.75 \\
\hline 5 & Donny Hidayat & 09.1 .03 .02 .0181 & 1 & 0.5 & 0.25 & 0.25 & 1 \\
\hline 6 & $\begin{array}{l}\text { Endang Restu } \\
\text { Patmawati }\end{array}$ & 09.1 .03 .02 .0200 & 0.5 & 0.75 & 0.5 & 0 & 1 \\
\hline
\end{tabular}

Gambar 5. Nilai Fuzzyfikasi 
Selanjutnya Menentukan rating kecocokan setiap alternative pada setiap kriteria. Berdasarkan data pemohon di atas dapat dibentuk matriks keputusan X yang telah dikonversikan dengan bilangan fuzzy sebagai berikut:

\begin{tabular}{|llllllllll|}
\hline SAW & & & & & & & & \\
No & Nama & NIM & C1 & C2 & C3 & C4 & C5 & V \\
1 & $\begin{array}{l}\text { Amirudin Sukma } \\
\text { Hanggara }\end{array}$ & 10.1 .03 .02 .0051 & 0.5 & 0.33333 & 0 & 0 & 0.75 & 0.15833 \\
\hline 2 & Arik Dwi malinda & 10.1 .03 .02 .0094 & 0.5 & 0.33333 & 0 & 0 & 0.75 & 0.15833 \\
3 & Astutik & 10.1 .03 .02 .0103 & 1 & 0.5 & 0 & 0 & 0.75 & 0.3 \\
\hline 4 & Arga Adinata & 10.1 .03 .02 .0088 & 0.5 & 0.33333 & 0 & 0 & 0.75 & 0.15833 \\
5 & Donny Hidayat & 09.1 .03 .02 .0181 & 1 & 0.5 & 0 & 0 & 1 & 0.3 \\
\hline 6 & $\begin{array}{l}\text { Endang Restu } \\
\text { Patmawati }\end{array}$ & 09.1 .03 .02 .0200 & 0.5 & 0.33333 & 0 & 0 & 1 & 0.15833 \\
\hline
\end{tabular}

\section{Gambar 6. Nilai SAW}

Setelah dilakukan Perhitungan ke SAW, Hasil akhir diperoleh dari proses perankingan yaitu penjumlahan dari perkalian matriks ternormalisasi $\mathrm{R}$ dengan vektor bobot sehingga diperoleh nilai terbesar yang dipilih sebagai alternatif terbaik sebagai solusi rekomendasi penerima beasiswa tampak seperti gambar 6 .

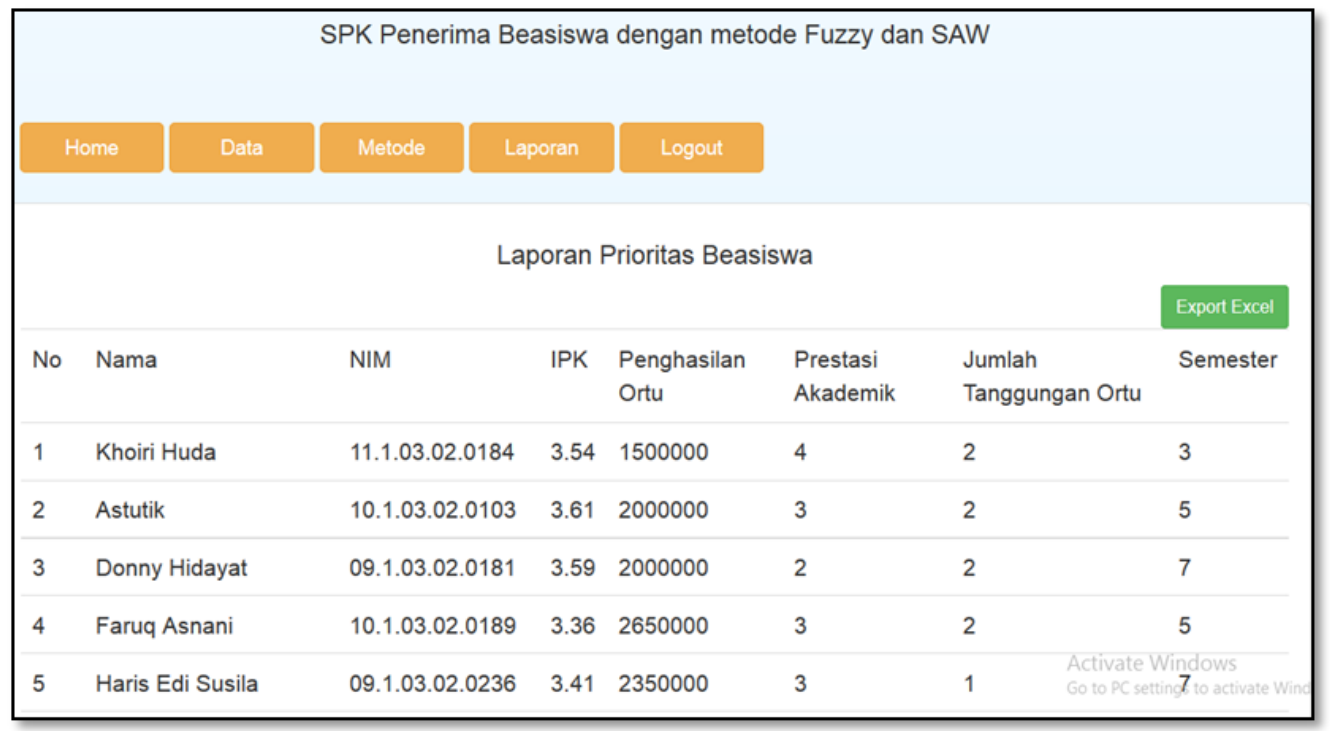

Gambar 7. Laporan prioritas Beasiswa

\section{KESIMPULAN}

Setelah melakukan analisis, perancangan, implementasi dan pengujian, maka dapat diperoleh kesimpulan sebagai berikut:

1. Penelitian ini telah menghasilkan sebuah sistem dengan Meode Fuzzy database model Tahani dan metode SAW dapat digunakan dalam memerikan rekomendasi penerimaan beasiswa.

2. Penelitian ini telah menghasilkan sistem pendukung keputusan untuk penerima beasiswa. Adapun variabel yang dijadikan bahan pertimbangan yaitu nilai IPK, penghasilan orangtua, prestasi non akademik, jumlah tanggungan orangtua, semester. 
3. Ada 2 metode yang diterapkan yaitu Logika Fuzzy Tahani sebagai nilai input ke SAW dan nilai output nya berupa perangkingan yang dapat merekomendasikan penerimaan beasiswa. Sistem ini dapat membantu pihak prodi untuk meberikan rekomendasi penerima beasiswa sesuai dengan kriteria yang diinginkan.

\section{SARAN}

berikut:

Adapun saran-saran bagi yang ingin mengembangkan penelitian ini adalah sebagai

1. Dilakukan penambahan variaebel untuk kriteria penerima beasiswa dan penambahan jenisjenis beasiswa.

2. Bisa dikembangkan dengan metode MADM yang lainnya.

\section{DAFTAR PUSTAKA}

[1] Kusumadewi, S., Hartati, S., Harjoko, A., Wardoyo, R., 2006, Fuzzy Multi Atribute Decision Making Fuzzy MADM, Penerbit Graha Ilmu, Yogyakarta.

[2] Turban, E., Aronson, J. E., Liang, T., 2005, Decision Support System and Intelegent System (Sistem Pendukung Keputusan dan sistem Cerdas), Penerbit Andi, Yogyakarta.

[3] Nasution, I. A., 2014, Sistem Pendukung Keputusan Penentuan Pemilihan Laptop Dengan Menerapkan Fuzzy Tahani, Pelita Informatika Budi Darma, No. 1, Vol. VI, Hal. 93 - 96.

[4] Putra, D., 2014, Sistem Pendukung Keputusan Untuk Menentukan Penerima Bea Siswa PT.Telkom Menggunakan Metode Simple Additive Weighting, Informasi dan Teknologi Ilmiah (INTI), No. 2, Vol. III, Hal. 1-7.

[5] Rohayani, H., 2013, Analisis Sistem Pendukung Keputusan Dalam Memilih Program Studi Menggunakan Metode Logika Fuzzy, Jurnal Sistem Informasi (JSI), No. 1, Vol. 5, Hal. 530539.

[6] Efendi, R., Ernawati, Hidayati, R., 2014, Aplikasi Fuzzy Database Model Tahani Dalam Memberikan Rekomendasi Pembelian Rumah Berbasis Web, Jurnal Pseodocode, No. 1, Vol. 1, Hal. 32-43. 